\title{
EENIGE AANVULLINGEN OP DE ENCYCLOPAEDIE VAN WEST-INDIE
}

\author{
HET MUNTWEZEN IN SURINAME
}

DOOR

C. R. WEIJTINGH

Kort na het uitbreken van den wereldoorlog in 1914 werd den Gouverneur bij Verordening van 18 Augustus 1914 (G.B. No. 49) de bevoegdheid gegeven om in dringende omstandigheden tijdelijk den uitvoer van munt en muntmateriaal geheel of gedeeltelijk te verbieden voor de geheele Kolonie of bepaalde gedeelten daarvan. Deze maatregel werd genomen vanwege het groote belang dat voor de Kolonie er in gelegen was om in de toen heerschende omstandigheden de munt en het muntmateriaal binnen de Kolonie te houden.

Van deze bevoegdheid behoefde door den Gouverneur echter geen gebruik te worden gemaakt omdat de kosten verbonden aan de verzending den uitvoer practisch onmogelijk maakten.

De in het begin van dien oorlog ook in Suriname ingetreden spanning, zich voornamelijk uitende in de vraag naar munt, waarvoor papier ter inwisseling werd aangeboden, heeft het Koloniaal bestuur geen aanleiding behoeven te geven om andere buitengewone maatregelen te nemen; die spanning kon spoedig ophouden doordien de circulatiebank (de Surinaamsche bank) zich onthield van het nemen van buitengewone maatregelen en bovendien zooveel mogelijk steun verleende waar zulks eenigszins mogelijk was.

Dat de bank zich onthield van buitengewone maatregelen, als b.v. in de eerste plaats kon verwacht worden, nl. het verzoek om verlaging van het vastgestelde bedrag van de verplichte dekking harer direct opeischbare verbintenissen, is dan ook ongetwijfeld van goeden invloed geweest.

Zelfs in de meest critieke dagen kon de bank blijven boven het 
bedrag dier verplichte dekking. In haar streven in dit opzicht werd zij van bestuurszijde gesteund, doordien in de gouvernementskassen slechts het hoogst noodige bedrag aan munt werd vastgehouden; waar munt gemist kon worden, werd deze bij de bank ingewisseld voor papier.

Ook ging de bank, toen reeds bij den aanvang van den oorlog bleek dat de uitvoer van goud feitelijk uitgesloten was, doordien deze slechts ten koste van groote opofferingen zou kunnen geschieden, met opkoopers en goudzoekers eene overeenkomst aan, waarbij zij aannam het aangeboden goud te koopen tegen een prijs, dien zij in gewone tijden gewoon waren te bedingen.

Hierbij stond tweeërlei doel voor oogen, n.l. zooveel mogelijk den gewonen gang in het goudbedrijf te bevorderen en om"zooveel mogelijk muntmateriaal te verzamelen in verband met de eischen, welke haar gesteld werden door de verzilvering van haar bankpapier en door buitengewone credietaanvragen.

Dit laatste doel werd volkomen bereikt.

In het geldverkeer te Albina in het grensdistrict Marowijne heerschte in 1916 een schaarschte aan Nederlandsche munt en een overvloed aan Fransch zilvergeld. De Surinaamsche bank verleende haar medewerking ter verbetering van den toestand door eene groote hoeveelheid Fransch ruilmiddel uit het verkeer aldaar te nemen en daartegen Nederlandsch zilver geld beschikbaar te stellen.

In de eerste maanden van het jaar 1918 ontstond er schaarschte aan zilveren munt, waarin noch uit den bij de Surinaamsche bank aanwezigen voorraad noch tijdig door aanvoer van uit Nederland kon worden voorzien.

Dit gebrek aan zilveren munt werd met vrij groote zekerheid toegeschreven aan de omstandigheid dat de kleinlandbouwers, die voor voedingsgewassen prijzen maakten, als nooit te voren, belangrijke bedragen aan zilveren munt vasthielden, omdat zij dat geld niet dadelijk noodig hadden en het niet rentegevend konden of wilden uitzetten.

De Gouverneur besloot toen om, in navolging van hetgeen in Nederland reeds in 1914 was geschied, over te gaan tot de uitgifte van zilverbons.

Krachtens de Verordening van 6 April 1918 (G.B. No. 25) werden uitgegeven 100.000 bons van $f 0.50,225.000$ van $f 1$. - en 90.000 van $f 2.50$, alzoo te zamen tot een bedrag van $f 500.000$.Dit bedrag werd later (bij Verordening van 19 October 1920 G.B. 
No. 71) verhoogd tot $f 800.000$. - , terwijl bij Besluit van 23 November 1920 (G.B. No. 89) werd bepaald dat ten hoogste zouden worden uitgegeven 100.000 zilverbons van $f 2.50,400.000$ van $f 1$. - en 300.000 van $f 0.50$.

Toen de zilverbons in omloop kwamen, verminderde de vraag naar zilver gaandeweg, terwijl de getroffen maatregel om het aan de kassen van de Surinaamsche bank aangeboden zilvergeld zooveel mogelijk in te houden, geleidelijk een gunstig gevolg had op den muntvoorraad der bank.

$\mathrm{Na}$ de totstandkoming van de Wet tot verlaging van het zilvergehalte van de grove Nederlandsche munt tot 720 , had de Regeering aan het Koloniaal bestuur opgedragen de noodige maatregelen te nemen om wegvloeiïng van de grove zilveren specie tegen te gaan en die te verzamelen en naar Nederland op te zenden ter ontmunting.

Toen de zilverprijzen in 1919 bleven stijgen en weldra een hoogte hadden bereikt waarop uitvoer of omsmelting van de zilveren munten van het oude geahlte voordeelen konden opleveren, werd bij Besluit van den Gouverneur van 5 Januari 1920 (G.B. No. 1) de uitvoer van Nederlandsche zilveren munt en van zilveren muntmateriaal tijdelijk verboden. Verdere maatregelen bleken niet noodig daar vrijwel al het beschikbare zilver bij de Surinaamsche bank aanwezig was. Ook tot de buiten-omloopstelling behoefde niet te worden overgegaan tengevolge van de daling van den zilverprijs. Wel werd bij Publicatie van 8 Juli 1920 (G.B. No. 42) afgekondigd het Koninklijk Besluit van 15 April 1920 No. 61 (Stbl. No. 184) houdende regeling van de wijze waarop de in art. 3 der Wet van 27 November 1919 (Stbl. No. 786) bedoelde rijksdaalders, guldens en halve guldens buiten omloop worden gesteld, doch de vaststelling van het tijdstip van buiten werking stelling door den Minister van Koloniën geschiedde eerst in 1934 en de gelegenheid tot inwisseling werd opengesteld tot 31 December 1937.

Van Landswege werd in 1921 Nederlandsche munt ingevoerd tot een bedrag van $f 380.000$. - en in 1922 tot een bedrag van $f$ 120.000.- .

De maatregel tot uitgifte van zilverbons kon daardoor in den loop van 1922 worden beperkt tot de uitgifte van zilverbons van $f 2.50$ alleen, door de intrekking bij Besluit van 1 Juni 1922 (G.B. No. 42) van de zilverbons van $f$ 1. - en $f$ 0.50. Deze buiten omloop 
gestelde bons konden binnen een daarvoor gestelden termijn (15 September 1923) uitsluitend bij de Surinaamsche bank worden ingewisseld.

Op 31 December 1922 waren uitgegeven en in omloop 76000 zilverbons van $f 2.50$ en nog niet ingewisseld 40000 bons van $f 1$. en 128.000 bons van $f 0.50$. In 1922 werden ingetrokken en vernietigd 38000 bons van $f 2.50,320.000$ van $f 1$. - en 52.000 van t 0.50 .

Het achterhouden van alle zilvergeld dat in de kassen van de Surinaamsche bank en in de landskassen binnenkwam, kon toen worden gestaakt. Geleidelijk werd dit zilvergeld, mede door de inwisseling der ingetrokken zilverbons weder in circulatie gebracht. Het bedrag van $f$ 1.106.500.- dat aan Nederlandsche zilveren munt bij de bank in voorraad was op 31 December 1921 daalde tot $f$ 856.000. - op hetzelfde tijdstip in 1922.

Op 17 Mei 1926 werd een bedrag van $f 28575$. - aan versleten munten ter inwisseling naar Nederland verzonden. Daarvan werden op 6 Juli 1926 in Suriname terugontvangen $f$ 21.000.- aan guldens, $f 5575$. - aan 5 cent stukken en $f 2000$. - aan 1 cent stukken.

Aan het publiek werd daarop tot eind December 1926 de gelegenheid gegeven tot inwisseling tegen gangbare munt van de ronde nikkelen stuivers, welke bij Koninkl. besluit van 21 Januari 1914 (Stbl. No. 23) buiten omloop gesteld, destijds ook in Suriname werden ingetrokken, maar kort daarop wegens schaarschte aan pasmunt weder uitgegeven en sedert tijdelijk in omloop waren gelaten.

Op 23 Juni 1928 werd voor een bedrag van $f$ 18.680.- aan versleten munten naar Nederland ter inwisseling verzonden alsook een bedrag van $f 4.800$. - rond aan ingetrokken ronde nikkelen stuivers, in de plaats waarvan $f 24.000$. - aan pasmunt werd terug ontvangen.

Bij Besluit van 11 Juni 1928 (G.B. No. 39) werden eindelijk ook de zilverbons ter waarde van een rijksdaalder buiten omloop gebracht; deze bons konden binnen een daarvoor gestelden termijn (30 Juni 1929) uitsluitend bij de Surinaamsche bank worden ingewisseld.

Het Besluit van 5 Januari 1920 (G.B. No. 1) houdende verbod van den uitvoer van munt en muntmateriaal werd bij dat van 28 
Augustus 1929 (G.B. No. 62) ingetrokken; toen de uitvoer van zilveren munten hierdoor weder mogelijk werd ,ging de handel daartoe weldra over in verband met de geringe daaraan verbonden kosten en de beperking van de afgifte van wissels welke de Surinaamsche bank had toegepast.

Het werd daardoor echter noodig dat, om stremming in den geldsomloop tegen te gaan, van Landswege regelmatig voor terugzending van het uitgevoerde zilvergeld werd gezorgd. Tegenover eene som van rond $f 762.000$. - welke per pakketpost werd uitgevoerd, stond een aanvoer van $f 800.000$. - een en ander van 6 September 1929 tot 30 April 1930.

In verband met de voorgenomen buiten omloopstelling met 1 Juli 1935 van de standpenningen van het gehalte van 0.945 werd daarvan tot een bedrag van $f 600.000$. - aan de circulatie onttrokken en naar Nederland opgezonden en vervangen door standaardmunt van 0.720 zilvergehalte, welke tot gelijk bedrag van te voren uit Nederland was aangevoerd.

Het verlaten van den gouden standaard door Nederland op 25 September 1936 is ook voor Suriname van invloed geweest. Ten einde mogelijke nadeelige gevolgen daarvan te beperken, is op 27 September 1936 (G.B. No. 138) met toepassing van art. 1 van de Verordening van 18 Augustus 1914 (G.B. No. 49) houdende verbod van den uitvoer van munt en muntmateriaal door den Gouverneur een besluit uitgevaardigd houdende verbod van den uitvoer van goud, hetzij in den vorm van munten, staven, baren, stofgoud, goudhoudende ertsen of kwartsen, geheel of gedeeltelijk van goud vervaardigde voorwerpen, dan wel in eenigen anderen vorm. Van de bij dit besluit opengestelde mogelijkheid om zoo noodig, onder te stellen voorwaarden ontheffing van dit verbod te verleenen, is door den Gouverneur in alle gevallen, waarin die ontheffing werd gevraagd en welke zich bepaalden tot uitvoer naar Nederland, gunstig beschikt. Voor de metaaldekking der Surinaamsche bank, welke steeds verzekerd is geweest door den zilveren muntvoorraad, leverde de toegestane uitvoer geen bezwaar.

Sedert den aanvang der inwisseling van oude munt in 1934 is aan nieuwe teekenpunt naar Suriname verscheept $f 1.000 .000$.in ruil waarvoor in $1936 f 990.429$. - en in $1937 f 25.500$. - aan oude munt naar Nederland werd opgezonden.

Ten slotte zij nog vermeld dat de Staatscommissie voor het 
muntwezen bij haar in Maart 1926 aan de Koningin uitgebracht advies zich niet heeft beziggehouden met den toestand van het muntwezen in Suriname, welk gewest krachtens de Wet van 1 Juli 1909 (Stbl. No. 212) dezelfde muntregeling heeft als Nederland. Wel heeft de Commissie in haar hiervoren bedoeld advies geconstateerd dat het financiewezen in Suriname, evenals in $\mathrm{Ne}-$ derland, in een ongewenschten toestand was gekomen.

Bronnen:

Verslagen van Bestuur en Staat, vroeger genaamd Surinaamsche Verslagen van $1916 \mathrm{t} / \mathrm{m} 1935$.

Handelingen der Koloniale Staten van Suriname van 1916 t/m 1935.

Jaarverslagen der Surinaamsche bank van 1916 t/m 1935 . 